\title{
The Behavior Of Bureaucracy in Application of Transparency, Participatory, and Accountability Services Procurement at Sidenreng Rappang Regency
}

\author{
Dr. Jamaluddin Ahmad, S.Sos, M.Si (Corresponding author) \\ Dept. of Public Administration, The Social and Political Science College Muhammadiyah \\ Rappang \\ PO Box 91651, Sidrap-South Sulawesi, Indonesia \\ Tel: +6281241560777Ｅ-mail: jahmadlado@yahoo.co.id

\begin{abstract}
Astinah Adnan, SS, M.Si
Dept. of Government, The Social and Political Science College Muhammadiyah Rappang Tel:+6281342911177_E-mail: stisipm_sidrap@yahoo.com
\end{abstract}

Published: March 31, 2014

doi:10.5296/jpag.v4i1.5451 URL: http://dx.doi.org/10.5296/jpag.v4i1.5451

\begin{abstract}
Application of transparency, participation, and accountability in the procurement process of goods and services is in need to achieve good governance. Local governments Sidenreng Rappang has committed to implement through regulation principles so important to study. Therefore, this study aims to determine the principles of transparency, participation, and accountability and bureaucratic behavior that influence the process of procuring goods and services.

This type of research is descriptive qualitative data collection techniques through documents, questionnaires, and informants. The data were then analyzed using qualitative descriptive analysis.

Behavioral results showed that bureaucracy tends political types in the application of the principles of transparency, participation, and accountability services for goods and services. This supported the existence of a Representative Observer of Society (ROS) that help implement it. The factors that influence still more in human resources and the enforcement of sanctions against irregularities rules or procedures.
\end{abstract}

Keywords: The Bureaucratic Behavior, Transparency, Participatory, and Accountability 


\section{Introduction}

Sidenreng Rappang have one area that consistently organize the system of governance (good governance). Conditions worsened responsibility for the implementation of the decree No. 08 of 2006 on the Action Plan Three Key Initiatives Towards Good Governance in the Context of Urban Sector Development Reform Project (USDRP) are Transparency, Participatory and Accountability (TPA).

The third principle is a concept that is often a concern in the discussion of public administration, especially against the phenomenon of state administration. National crisis and the problems that plagued the nation of Indonesia has been essentially derived from the weakness in this area, especially the bureaucracy that ignores the principles of good governance. The high corruption cases accompanied by collusion and nepotism that occurs is a major cause of failure in good governance and clean.

Accordingly, through the People's Consultative Assembly (MPR) decree number 1999 XI on State Officials are clean and free of corruption, and the Law. 28 Year 1999 on State Implementation of Clean and Free from Corruption, Collusion and Nepotism, Indonesia confirms its determination to continue to earnestly realize the state administration and development based on the principles of good governance.

To explore the phenomenon of bureaucratic behavior in transparency, participation and accountability in order to achieve good governance, then the locus of interest is the process of procurement of goods and services in the local government sector. This is reasonable considering the sector has a public component that involves a partnership of government, people, and businesses (private).

From the background of the above problems, the purpose of this study is a portrait of bureaucratic behavior in the application of the principles of Transparency, and Accountability in the participatory process in the procurement of goods and services Sidenreng Rappang regency, and analyzes the factors that influence it.

\section{Overview of the Literatur on The behaviors of bureaucracy and good governance}

Salusu (2008:442) divides the type of behavior consists of employee career bureaucrats, politicians, professionals, and missionary. Type of career employees who identify career employee characterized and awards received by the organization where he worked. He did not think to move and want to maintain a position within the organization. The type of politician that bureaucrats are trying to pursue a career outside the organization, whether in the office or appointed through elections. For him, the important thing is to keep maintaining relationships with a variety of power sources outside the organization, with the hope of a future resources it offers a position for him. The type of professional that bureaucrats who were satisfied with the professionalism of the award given to him by the profession or the other based on the ability to demonstrate their competence as professionals. Type missionary makes a bureaucrat maintaining loyalty to a decision or wisdom and wish hard that decision was implemented in the manner intended, without thinking of his career, or other positions outside of, or recognition profession. 


\section{Macrothink}

Types are not likely to be found separately. In general, the type of which one to join another type. Similarly, one type can last for a moment, then turned to other types at different times and occasions. Behavioral change is desired or expected in the educational process, can occur through changes in knowledge, attitudes, and skills or their respective direct impact on behavior change, although the latter condition can occur with ease.

Bureaucrats might never think to move to another job, but if there is a chance, he would use it. However we analyze the types of bureaucratic behavior, can not be denied the strengths and weaknesses of each. It is important to know, as long as the bureaucrat to do his job, he should carry out their duties in accordance with the criteria that have been expressed. Thus, the types of behavior is what a lot of coloring process of public policy. As further proof of assertion, then for the purposes of this type of search is conducted through a career employee, the type of politician, professional type, and the type of missionary. Although Salusu (2008:442) asserts that these types will not likely be found separately, so it could be concluded that the emerging type of eclectic.

A wide range of government bureaucracy that can arise due to differences in the characteristics and functions of bureaucratic actors, with an emphasis on administrative behavior, Bryant and White (1989:106) divides three basic approaches models in explaining the behavior associated with the analysis of the organization, namely the rational model, the model social-psychological, and developmental model of human relationships.

Bureaucrats who are rational and well have a self-interest, he will not automatically be willing to serve on the organization's objectives. Therefore, organizations must develop structures and incentives that channeled his interests so aligned with the interests of the organization. Etzioni (1961) described three forms of trade-services or three types of sanctions are used to gain compliance, namely physical, symbolic, and material. If the purpose of the organization is to produce actual goods or services, it is appropriate to use public bureaucracy material incentives and rewards such as peace-material services.

Similarly, the concept of good governance in public administration can be traced through various approaches, by Thomas Khun (in Sinambela, 2008:11) referred to as a perspective paradigm defined group of scientists in a given period where there is a group of scientists who emphasize a particular subject matter, including the conceptual framework and methodology in a period, and at another period emerged a group of other scientists who have a different view. The underlying view of a group of scientists on a scientific object of study, including methodology.

Henry (2004:30-50) suggests a paradigm of public administration as follows: (a) The first paradigm (1900-1926) political and administrative dichotomy; (b) The second paradigm (1927-1937) referred to as a paradigm Principles of Administration; (c) The third paradigm (1950-1970) referred to as a paradigm of Public Administration Political Science; (d) The fourth paradigm (1956-1970) is a Public Administration Administration; (e) The fifth paradigm (1970-present) is a recent paradigm known as the Public Administration Public Administration.

In addition to Henry Nocholas opinion, there is also the opinion Caiden (1982) detailing there 
is some flow in public administration is the administration process flow, empirical flow, flow behavior, flow analysis of bureaucracy, social system flow, the flow of decision-making, mathematical flow, and flow integrative. All streams are implemented in the public administration. Despite all the flow divided by Caiden only in outline, namely flow and administrative processes a holistic flow.

Kettl (1993: 409-412) also reveals the paradigm of public administration in the form of four stages of development, namely the centrality of the administration stage (1887-1915), scientific management phase (1915-1940), critical self-test phase (1940-1969), and stage the centrifugal factors (1969-present).

These paradigms only until the end of 1960 or beginning of 1970 . Ten years later in 1983 there is a new paradigm that appears to revise POSDCORB submitted by Garson and Overmann in an acronym form is also called as PAFHRIER, stands the Policy Analiysis, the Financial, Human Resources, Information, and External Relations. This paradigm then become the focus of public management (Garson \& Overmann, 1991).

Approximately ten years later, a paradigm shift, which is known as the post-bureaucratic paradigm by Barzelay (in Keban, 2008:35) which is different from the bureaucratic paradigm that many people criticized. This paradigm emphasizes the useful results for society, quality and value, product, and attachment to the norm. This paradigm also emphasizes the mission, service and end result. Also pay attention to the understanding and application of norms, identifying and solving problems, as well as the continuous improvement process. Last paradigm emphasizes the separation between the control service, building support for the norms, expanding customer choice, encourage collective activities, provide incentives, measure and analyze the results, and enriching feedback.

At the same time in the United States appear very well-known paradigm called Reinventing Government and delivered by D.Osborne and T.Gaebler then operationalized by Osborne and Plastrik (2000:322-324) regarding the governance principles of entrepreneurship. These principles consist of: (1) the catalyst rule, (2) the government belongs to the people, (3) competitive government, (4) the mission-oriented government, (5) results-oriented government, (6) government-oriented customers, (7) self-employment rule, (8) anticipatory governance, (9) a decentralized government, (10) market-oriented government.

The principle of this paradigm in the UK known as New Public Management (NPM) popularized by Hood cited by Eran Vigoda (in Keban, 2008:36) which revealed that there are seven components of the doctrine in this paradigm, namely: (1) the use of professional management in public sector, (2) the use of performance indicators, (3) a greater emphasis on output control approach, (4) a shift of attention to the units smaller, (5) the shift to higher competition, (6) an emphasis style private sector management practices, and (7) an emphasis on discipline and higher savings in the use of resources.

It should be the emphasis here that the paradigm of New Public Management (NPM) and Reinventing Government arising out of the public discontent against the government.

Approximately ten years later, around 2003 emerged a new paradigm by Denhardt and Denhardt (2006:444) that offers a service model that is called with a new public service 
model (the new public services). This model rests on the theory that teaches the existence of an egalitarian democracy and equality among citizens. Bureaucracy which provide public services should be accountable to the community as a whole with an emphasis on the public interest.

Public administration in this paradigm can not be separated from the new public service that is also more influenced by Denhardt and Denhardt, (2006:42-43) which is famous for the fundamental principles of public service New Public Service: (a) Serve citizens, customers Not (b) Seek the public interest; (c) Value citizens over Entrepreneurship; (d) Think Strategically, Act Democratically; (e) Recognize that Accountability Is Not Simple, (f) Rather Than Serve Steer; (g) Value People, Not Just Productivity.

Then, G.Shabbir Cheema (in Keban, 2008:37-38) revealed four phases of public administration which also describes the development of public administration paradigm, namely: (a) Traditional public administration, (b) Public Management; (c) New Public Management (d) Governance. Governance is defined as a system of values, policies, and institutional affairs in which economic, social, political and administered through the interaction between society, government and the private sector.

Finally, in today's governance gets the most attention from various countries through the invitation of the United Nations Development Program (UNDP) with the use of the term good governance. By Rondinelli (2007:9) consists of: participation, rule of law, transparency, responsiveness, consensus orientation, equity, effectiveness and efficiency, accountability, and strategic vision.

Then developed by Development Planning Agency (Badan Perencanaan Nasional), (1) foresight, (2) openness and transparency, (3) public participation emphasis, (4) accountability, (5) rule of law, (6) democracy, (7) professionalism and competence, (8) responsiveness, (9) an emphasis on efficiency and effectiveness, (10) decentralization, (11) partnership, (12) commitments on reducing gaps, (13) a commitment to environmental protection, and (14) a commitment to a fair market.

Based on the various paradigms that have been described show that in recent decades there has been a change in the orientation of public administration quickly. Although in essence, according to Thoha (2008:83-83) that studied the development of public administration can be grouped into three sections or periods of the Old Public Administration, New Public Management and New Public Service.

Old Public Administration, centered on the notion Woodrow Wilson, Fredrick Taylor, Luther Gulick, and Herbert Simon. The main emphasis in this period are: (1) an overview of the science is neutral and value-free, (2) norms that should be used as a guide in setting and implementing public organizations, (3) the role of public administration or government bureaucracy, especially to do with politics and principle efficiency, and (4) control is done from the top down.

The New Public Management, with the main emphasis is to change how the public bureaucracy to deliver business performance and transforming the label into it. Labor market orientation should also be applied in a way to recognize people as customers. 
The New Public Service, with the main emphasis on the concept of the various elements. The basic idea of this concept on (1) the theory of democratic citizenship, (2) a model community and civil society, (3) organizational humanism, (4) and postmodern science of public administration.

Without prejudice to the development paradigms that have been described, the meaning of good governance According to Lukman Hakim Saifuddin (2000:1) good governance (good governance) can be interpreted as a mechanism of resource management with the substance and implementation aimed at achieving efficient development fair and effective manner. Therefore, good governance will be created when the elements of the state and societal institutions (organizations, NGOs, the press, professional bodies, private business organizations, etc.) have a balance in the process of checks and balances and should not be one in the those who have absolute control.

This can only be achieved if applied the principles of transparency, participation, and accountability as an integral of good governance.

Transparency means that enough information is available, accurate and timely information about public policy, and the process of its formation. With the availability of such information, the public can participate as well so keep an eye on emerging public policy can deliver optimal results for society, and prevent fraud and manipulation that benefit only one group of people disproportionately. Within this framework, the role of Parliament as a representative institution of the people to be important, as well as the press, which is a bridge between the power elite and the information society (Sjahrir, 2001: 21).

Accountability by creating meaningful oversight over the distribution of power in the various government agencies, thereby reducing the accumulation of power while creating the conditions studied each other (checks and balances system). Government agency in question is the executive (president, vice president, and cabinet), the judiciary (the Supreme Court and the judicial system), and legislative (Sjahrir, 2001: 21).

In the legal and political framework, it is clear that the Constitution has mandated the implementation and operation of political and legal policy of the state bureaucracy. In turn, these policies elaborated and given a concrete and tangible containers in a program of so-called public policy. It is difficult today to deny the existence of a public perception that the concept of good governance has not been implemented properly. Ambiguity and lack of accountability within the decision-making process, for example, making people always overwhelmed by questions, whether it is true that their interests are always prioritized.

According to Dadan Solihin (2000: 2) in an effort to reach the condition of civil society can con rembung to build the nation together with the government, this transition is very appropriate to be used as a stepping stone to towards a society that: (a) Trusting government policy; (b) Not just a "tut wuri handayani" but also have the ability to understand the foundation of government thinking and behavior; (c) Feel a significant part in the decision by the government; (d) Participation in developing countries.

Good governance is not itself able to guarantee the implementation of the people's welfare and the interests of the state. Therefore, good governance does not mean to undermine the 
roles needed to carry out the functions as state officials and development. For a modern and democratic state requires power and greater authority, in order to direct, formulate and implement public policies. The problem is, how to keep the implementation of the authority and power still has the responsibility and accountability, as well as how to provide a means to ensure the creation of executive responsibility and accountability to the community and council representatives.

Good governance requires quality resources that will contribute systematically prepare strong political leadership. This relates to how the capabilities and resources of political strategies to anticipate problems in the community. Quality will be observed from its ability in processing information into a series of policies, explanations and political forecasts, which in turn will shape the dynamics of the expansion of participation,development programs, political attitudes and policies in the legislature. With this strategy, then the resources will be able to develop a political party acts as a measure of the information developed at the public level.

In line with the Local Government Act, local governments as part of state officials are also required to observe the principles of the organization of the State in carrying out its duties, to enable the creation of good governance and authoritative.

To realize local government clean and respectable, priority development areas of the state organization aimed at improving performance of bureaucratic red tape in order to be able to create conditions conducive to the needs of the community, improving the quality of service to the community, and reduce the level of misuse of authority within the government apparatus. Indicator of a government's performance can be measured based on the principles of good governance, namely accountability, participation, and transparency.

\section{Research Methods}

This study uses phenomenological models because it is a model that describes the study of the meaning of life experience of some individuals. For this purpose there are four techniques of data collection in this study, namely: literature, observations, interviews, and documentation. The technique of data analysis is the reduction, presentation and drawing conclusions. Conducted technical examination of the validity of the data, especially examining the information obtained in the field, based on the results of the planning documents and field data. Test confidence by extending the observations, increasing persistence, triangulation, negative case analysis and use of reference materials.

\section{Results and Discussion}

\subsection{Type of bureaucratic behavior in Good Governance}

Good governance is the government providing various facilities, legal certainty, net in providing services, protection of various arbitrary acts both upon themselves, and property rights. In the form of partnerships, there is a branch of government that relate directly to the people that the procurement of goods and services. Practically any efforts towards good governance, provide convenience to the general public a wide range of collateral. And remember things that touch directly to the public, good governance is the effort to reform the system of state administration (bureaucracy) and procedures for law enforcement. 
Demands to create a system of state administration (government officials) are often regarded as an integral part of the process of creating the life of a democratic nation and state, as well as upholding the law in the true sense. Administration of the state can be interpreted as what the government or by agencies, ranging from the planning to the evaluation stage, and so on. The state administration activities also include attention to the aspirations of the people, process data / information, and present it to policy makers, as well as supervise, control and evaluate the implementation of public policy.

\subsection{Application of Participation}

The principle of participation encourages every citizen the right to use the expression in the decision-making process, which involves the interests of the public, either directly or indirectly. Participation is an organization of member involvement in all activities of the organization. Participation intends to ensure that any measures taken reflect the aspirations of the people. In order to anticipate the issues that exist, local governments provide a communication channel for people to express their opinions. This communication paths include public meetings, talks, consultations and delivery of a written opinion.

Community participation in the form of procurement of goods and services in Sidenreng Rappang has involved the community in the form of Representative Observer of Society. The people who sit in the Representative Observer of Society is chosen by the people through elections at the district level and district consisting of academics, teachers, and NGOs. They are tasked with monitoring every process of government procurement of goods and services that use the state budget, through the budget revenue and expenditure as well as revenue and expenditure budgets.

Another form is performed by the Representative Observer of Society is to stimulate community involvement through participatory planning is to prepare the agenda for the development, monitoring, evaluation and participatory monitoring and consultation mechanism to resolve sectoral issues. The Representative Observer of Society is the basic instrument of participation rules that guarantee the right to express opinions in the decision-making process, while supporting instruments are guidelines that accommodate the observations in the opinion of the right delivery and monitoring of all procurement processes.

Table 1. Partisipation by Representative of the public observer

\begin{tabular}{|l|l|l|l|}
\hline No. & Response Categories & Frequency & Percentage \\
\hline 1 & Optimal & 21 & $70 \%$ \\
\hline 2. & Less than optimal & 9 & $30 \%$ \\
\hline 3. & Not optimal & - & $0 \%$ \\
\hline 4. & Total & 30 & $100 \%$ \\
\hline
\end{tabular}

Source : Data that has been processed, 2013

Referring to the table shows that in general the behavior of the government bureaucracy in terms of political participation tend to type. This is supported $70 \%$ of the optimal answer has meaning efforts, local government bureaucracy seeking alternatives outside the organization to get the effect. They are able to influence the WPM members to behave in accordance with what they want, so that will someday power promising. 


\subsection{Application of Transparency}

Transparency is openness to all actions and measures taken by the government. The principle of transparency creates trust reciprocity between the government and the public through the provision of information and ensure ease in obtaining accurate and adequate information. Information society is an essential requirement to participate in the management area. In this regard local government Sidenreng Rappang proactively provide comprehensive information on the procurement of goods and services it provides. Local governments utilize multiple communication channels such as mass media (newspapers). Local governments set up a clear policy on how to get the information.

This policy will clarify the form that people can access information or confidential information form, how do I get the information, long time to get information and complaints procedures. Basic instrument of transparency is the rule that guarantees the right to obtain information, while supporting instruments is a facilities database and means of information and communication and dissemination of guidance and information products available, as well as complaints procedures.

Table 2, Transparency by Representative of the public observer

\begin{tabular}{|l|l|l|l|}
\hline No. & Response Categories & Frequency & Percentage \\
\hline 1 & Optimal & 25 & $93,33 \%$ \\
\hline 2. & Less than optimal & 5 & $16,67 \%$ \\
\hline 3. & Not optimal & - & $0 \%$ \\
\hline 4. & Total & 30 & $100 \%$ \\
\hline
\end{tabular}

Source : Data that has been processed, 2013

The tendency of bureaucracy assess implementation of the principle of transparency is $83.33 \%$ due to meet existing rules. They assess the presence of WPM will assist in disseminating information on the procurement of goods and services. WPM members will look for information in the media about the veracity of the information relating to the procurement of goods and services, for example through the media what, when loaded, and easily accessible by the public.

However, if the type of behavior associated with government bureaucracy prone to political types, because the reason they are announced in the media was so impressed implement the principles of transparency and, if judged by the community and its leaders will bring a positive value.

\subsection{Applying the Principle of Accountability}

Accountability is the ability to account for all the actions and policies that have been pursued. This principle implies increasing the accountability of decision makers in partnership procurement of goods and services. The entire policy makers at all levels to understand the measures taken and accountable to the public. To measure performance objectively using clear indicators. Strengthened surveillance system and published the results of the audit, and if there are errors sanctioned. This is often done when there is a refutation of the procurement auction. As a member of WPM statement, Ismail M which states: 
"We often hold meetings with precuremen anchor unit if no objections are filed by the partnership if they are not satisfied with the auction process. "(Interview, July 2013)

precuremen anchor the unit in this case is the District Secretary along with the rest of the elements of leadership work unit area as the responsible officials maker activity and commitment. When it is discussed at the level of the anchor unit precuremen then the client will accept the decision of the tender committee as a basic instrument of accountability in accordance with the laws and regulations that exist.

Table 3. General Views Of The Implementation Of Transparency

\begin{tabular}{|l|l|l|l|}
\hline No. & Response Categories & Frequency & Percentage \\
\hline 1 & Optimal & 15 & $30 \%$ \\
\hline 2. & Less than optimal & 35 & $70 \%$ \\
\hline 3. & Not optimal & - & $0 \%$ \\
\hline 4. & Total & 30 & $100 \%$ \\
\hline
\end{tabular}

Source : Data that has been processed, 2013

From the table above shows that there are 15 respondents or $30 \%$ of respondents who answered the optimal, the reason they are the local government officials have sought to provide services fast service and the right, if then the results are not as expected, according to them it is because of the emergence of it is not suspected. 35 respondents or $70 \%$ stated less than optimal, the reason they are intentionally extend any element of the bureaucracy in providing information.

Accountability of local government bureaucracy is the leader and boss. Hope then is leadership assessment results will hopefully be one of the positive values to develop his career thus attempted to seek support from outside the organization. Such support usually comes from members of the Regional Representatives Council.

\subsection{Factors Affecting Behavior of Bureaucracy in the Application of Transparency, Participation and Accountability}

\section{a. Human Resources}

Following the opinion of the respondents about the human resource oversee the implementation of the principles of transparency, participation, and accountability of procurement services.

Table 4. Opinions of Respondents (Government officials) on HR in Sidenreng Rappang

\begin{tabular}{|l|l|l|l|}
\hline No. & Response Categories & Frequency & Percentage \\
\hline 1 & Optimal & 12 & $40 \%$ \\
\hline 2. & Less than optimal & 18 & $60 \%$ \\
\hline 3. & Not optimal & - & $0 \%$ \\
\hline 4. & Total & 30 & $100 \%$ \\
\hline
\end{tabular}

Source : Data that has been processed, 2013

From the table above shows that all the respondents ie 12 respondents or $40 \%$ of respondents 
stated that human resources have been the optimum conditions in terms of procurement of goods and services. The reason they have not been put forward thus is no sanction to civil servants relating to the procurement of goods and services. 18 respondents or $60 \%$ of other respondents argued that human resources have not run optimally. Thus is the reason they put forward even though the sanctions have not been imposed on civil servants relating to the procurement of goods and services but still get mild sanction in the form of a reprimand. Violations they meant, among others, the persistence of the elements in some institutions which deliberately complicate bureaucracy.

In reality also, according to one member of the Regional Representatives Council in an interview stated that:

"... A lot of officers who did the interpretation that adapts to their interests or their group. This hinders the provision of services to the public because the apparatus itself must be conflicting because of differences in their interpretation of the rules. "

The ability of local government bureaucracy has also resulted in inadequate efforts to provide services and handle public complaints. Lack of socialization of the body or agency in charge of providing public assistance to resolve disputes between the public and public service agencies. No less important is the human resource. Ranging from human resource recruitment causes do not always have qualified as carrier providers of good governance.

\section{b. Certainty in the Law Enforcement}

Important function of law in an effort to exert social control. One of the things that can run the control function is law enforcement, especially in the application of sanctions against those who commit acts that deviate from the general principle of proper administration. Especially the implementation of the principles of transparency, accountability, and participation in the procurement process.

In fact at this time, although many officials who perform actions that deviate from the general principle of proper administration, but it is rare that sanctioned such actions ultimately be something taken for granted.

Not optimal application of legal sanctions against the officer, according to one sub-district head in Sidenreng Rappang in stating that:

Of deviation from the rules is due to two main factors, namely the lack of control of the employer and the lack of external control of society. This situation then entrenched in the bureaucracy of life. "

The interview results indicate that the lack of sanctions not because no offense but because of the lack of control over and control of the community. Although the existing control of representative observers society, but still limited to the provision of advice and input, the decision is in the hands of the bureaucracy itself, in this case the auction committee procurement of goods and services.

\section{Conclusion}

Based on the results of research and discussion in the previous section, it can be formulated 
some relevant conclusions as follows:

Bureaucratic behavior in the application of the principles of transparency, accountability, and participation services procurement tends type of politician, this is caused by the bureaucracy seeks power outside organization. They are trying to find the sources of power outside the organization who try to take advantage representatives and members of the public observers legislature to assure the implementation of the principles of transparency, participation, and accountability.

The factors that affect the application of transparent, participatory, and accountability is a factor of Human Resources and law enforcement or sanction to deviation procurement procedures.

\section{Reference}

Caiden, G.E. , (1982). Public Administration. Second Edition. California: Palisades Publishers.

Bryant, Coralie and Louise G. White. , (1989). Management Development for Developing Countries. Jakarta: LP3ES.

Dadang Solihin. Anti Corruption And Good Governance. Papers. Presented to the Weekly Discussion Development Secretariat of Public Good Governance Bappenas August 24, 2000.

Denhardt,(2004). The Public Service. New York: Oxford University Press.

Denhardt, Robert B. and Janet V. Denhard. (2006). Public Administration An Action Orientation. USA: Thomson Wadsworth.

Etzioni, Amitai. (1961). A. Comparative Analysis of Complex Organizations. New York: Free Press.

Hamidi, Jazim (editor), (1999). Broad Autonomy and Self Towards New Indonesia, Tarsito, Bandung.

Harkristuti Harkrisnowo (2003), Good Governance and Independence Bureaucracy, Paper, Jakarta

Haris Syamsuddin, (2005). Decentralization and Regional Autonomy, Indonesian Torch Foundation.

Henry, Nicholas. (2004). Public Administration And Public Affairs (Ninth Edition). New Jersey: Pearson Prentice Hall.

Kettl, D. F. (1993). "Public Administration: The State of the Field”. Political Science: The State of the Discipline II, edited by Ada W. Finifter. Washington, DC: the American Political Science Association.

Keban, Yeremias T. , (2008). Six Dimensions of Public Administration Strategic Concept, Theory, and Issues. Bandung: Publisher Gava Media

Kettl, D. F. (2000). The Global Revolutions: a report on the transformation of governance. Washington DC: Brooking Institution Press. 


\section{Macrothink}

Journal of Public Administration and Governance ISSN 2161-7104 2014, Vol. 4, No. 1

Lukman Hakim Saifuddin, A Note About Public Perception Regarding Good Governance In Indinesia. Papers. Delivered In Weekly Discussion Forum Secretariat Governance PublikGood Development, Bappenas RI, 24 - 11-2000

Made Kelvin, (2000), The format of the Regional Autonomous Province and District or City Under Law 22 of 1999 and Act 25 of 1999, Papers, Jakarta

Osborne, David and Peter Plastrik. , (2000). Trimming Bureaucracy Five Strategies Towards Entrepreneurial Government. Jakarta: Publisher PPM.

Prasodjo, Eko, (2006), Reconstruction Birthday Government Relations Central and Local Government of Indonesia; Between Sentripetolisme and Sentripugalisme, Inauguration Speech Professor Position in Public Administration, Social UI. Jakarta.

Rondinelli, D.A. (2007). "Governtment Serving People: The Changging Role of Public Administration in Democratic Governance" in Public Administration and Democratic Governance: Governments Serving Citizens. New York: United Nations: Economic and Social Affairs.

Salusu, J., (2008). Strategic Decision Making For Organizations Public and Nonprofit Organizations. Jakarta: Grasindo.

Sedarmayanti, (2003). Good governance, Bandung; Alfabeta.

Sinambela, Lijan Poltak. et al. , (2008). Public Services Reform (Theory, Policy, and Implementation) (Third Printing). Jakarta: PT. Earth Literacy.

Sjahrir, (2001), Good Governance in Indonesia Still Critical Review Utopia Good Governance, Paper, Jakarta.

Thoha, Miftah, (2003), Bureaucracy and Politics in Indonesia, UMM Press, Jakarta.

Timur Mahardika, (2000), Relation of War Pull Regional Center, LAPERA Pustaka Utama, Jakarta. 